\title{
Water quality challenges and impact
}

\author{
A. N. Obilonu ${ }^{1, a}$, C. Chijioke ${ }^{2, b}$, W. E. Igwegbe ${ }^{2, c}$, O. I. Ibearugbulem ${ }^{2, d}$, \\ Y. F. Abubakar ${ }^{2, \mathrm{e}}$ \\ ${ }^{1}$ Department of Agricultural Engineering, Federal Polytechnic, Nekede, Owerri, \\ Imo State, Nigeria \\ ${ }^{\text {a }}$ Phone: +2348033442899 \\ ${ }^{2}$ Department of Civil Engineering, Federal Polytechnic, Nekede, Owerri, \\ Imo State, Nigeria \\ ${ }^{\text {b,e }}$ Phone: $08932739132,+2348063812837,+2348035572448,+2348035003839$ \\ a,b,c,d,e E-mail address: tonysite.obilon2@gmail.com ,cj_uc2000@yahoo.com , \\ Walteremeka@yahoo.com.my ,donpeto_80@yahoo.com , fatiaburo@yahoo.com
}

\begin{abstract}
ABSTARCT
Man's activities on the environment often results in pollution and degradation of water bodies. Water bodies must therefore be jealously guided and protected from being polluted, which will affect water quality and availability for desired usage. Causes of water quality impairment are urban and rural storm water runoff, inadequate waste water treatment, nutrient entrophication, atmospheric deposition and acid rain, pollutant in sediments and fish, and nuisance aquatic weed growth and invasive species. Other factors include unhygienic disposal and inadequate treatment of human and livestock wastes, indecent management and treatment of industrial residues, inappropriate agricultural practices and unsafe solid waste discharge. Suggested strategies to combat water quality problems which should form the basis of policy solution for improving water quality include: (i) prevention of pollution; (ii) treatment of polluted water; (iii) safe use of waste water; and (iv) restoration and protection of ecosystem. It is recommended that our water bodies and the environment in general should be protected through appropriate legislation guidelines and public literacy campaign and mass education to sensitize, educate and make the people a fully environmentally literate society. Taking these steps internationally, nationally and locally will mean better water quality for our present society and future generation.
\end{abstract}

Keywords: Water quality; Environment; Pollution; Prevention; Treatment

\section{INTRODUCTION}

Water, though fluid, is the "backbone" of everything alive. This is because clean, safe, and adequate freshwater is vital to the survival of all living organisms, and the smooth functioning ecosystems, communities and economies. Water is utilized in diverse ways among which are: public (domestic) water supply, industrial water supply, agricultural water supply, fresh and marine water fisheries, recreational and other aesthetic enjoyments, and water transportation. Water bodies must therefore be jealously guided and protected from 
being polluted, which will affect water quality and availability for desired usage. Without water therefore, life and civilization cannot survive let alone develop and be sustained.

The aim of this study is to X-ray the water quality problems and challenges and their impacts, and suggest strategies of combating such problems.

\section{WATER QUALITY CHALLENGES AND IMPACTS}

Water quality is a terminology used to depict the physical, chemical and biological characteristics of water in relationship to a set of standards. Water quality is important because its uses covers virtually all corners of life, from personal human consumption to environmental and industrial application and even aquatic matter (Amund et al, 1991). In irrigation, water evaluation emphasis is on the chemical and physical characteristics of the water, and rarely are other factors considered important (Ayers et al, 1994). The quality of irrigation water is generally judged by its total salt concentration or electrical conductivity (EC), relative proportion of cations or sodium absorption ratio (SAR) and bicarbonate and boron content of water (Michael 1999).

Declining water quality has become a global issue of concern as human population grow, industrial and agricultural activities expand and climate change threatens to cause major alterations to the hydrological cycle. Water quality issues are complex and diverse and are deserving urgent global attention and action (UN - Water 2011).

Both natural processes and human activities influence the quality of surface waters and ground water. Some major water pollutants and their possible sources are listed in Table 1. The discharge of these pollutants into water bodies directly or indirectly will contaminate the water system and hence affect water quality and availability for desired usages.

The major sources of water pollution are from human settlement and industrial and agricultural activities. Negative factors related to these activities include unhygienic disposal and inadequate treatment of human and livestock wastes, indecent management and treatment of industrial residues, inappropriate agricultural practices and unsafe solid water discharge. For example:

i) Over 80 percent of sewage in developing countries is discharge untreated directly into water bodies (UNICEF and WHO, 2008).

ii) Industries are responsible for dumping an estimated $300-400$ million tones of heavy metals, solvent, toxic sludge and other wastes into water each year (UN Water 2011).

iii) Nitrates from agriculture are most common chemical contaminant in the world ground water aquifers (Morris et al, 2003 and Mahvi et al, 2005).

iv) In the united states of America, manures and pesticides from agriculture are the greatest source of water pollution (Revenga and Mock 2000, Faeth 2000).

In almost all countries with major land salinization; water salinization is an accompanying problem. Major problems have been reported in Argentina, China, India, Sudan, and many countries in central Asia where more than 10 million hectares of irrigated land are salinized (Ghassemi et al, 1995). 
Table 1. Sources of Pollutants to Surface Water.

\begin{tabular}{|c|c|}
\hline Sources of Pollution & \multirow{2}{*}{ Potential/Improve } \\
\hline MUNICIPAL AND RURAL SEWAGE & \\
\hline $\begin{array}{c}\text { Raw sewage } \\
\ldots \ldots \ldots \ldots \ldots \ldots \ldots \ldots \ldots \ldots \ldots \ldots \\
\end{array}$ & $\begin{array}{l}\text { Suspended solids, dissolved solids. High } \\
\text { BOD, nutrients. }\end{array}$ \\
\hline $\begin{array}{c}\text { Primary effluents } \\
\ldots \ldots \ldots \ldots \ldots \ldots \ldots \ldots \ldots \ldots \ldots \ldots \ldots \ldots \ldots \ldots \ldots \ldots\end{array}$ & Dissolved Organic, high BO nutrients. \\
\hline $\begin{array}{l}\text { Secondary Effluents } \\
\ldots \ldots \ldots \ldots \ldots \ldots \ldots \ldots \ldots\end{array}$ & Nutrients, virus \\
\hline $\begin{array}{c}\text { Septic tank effluents } \\
\ldots \ldots \ldots \ldots \ldots \ldots \ldots \ldots \ldots \ldots\end{array}$ & Nutrient \\
\hline $\begin{array}{c}\text { Urban runoff } \\
\ldots \ldots \ldots \ldots \ldots \ldots \ldots \ldots \ldots \ldots \ldots \ldots \ldots \ldots \\
\end{array}$ & $\begin{array}{l}\text { Mineral and soil sediments. Salt nutrients, } \\
\text { pesticide organic. }\end{array}$ \\
\hline \multicolumn{2}{|l|}{ LAND EROSION } \\
\hline Non-urban soil & $\begin{array}{l}\text { Mineral and soils sediments. Salts } \\
\text { nutrient, pesticides, Suspended Soils, } \\
\text { naturally Elements. }\end{array}$ \\
\hline $\begin{array}{c}\text { Animal wastes } \\
\ldots \ldots \ldots \ldots \ldots \ldots \ldots \ldots \ldots \ldots \ldots\end{array}$ & Suspended soils, high BOD. \\
\hline $\begin{array}{l}\text { Nutrient, bacteria and virus Mine } \\
\text { drainage }\end{array}$ & Acids, sediment, heavy metals suspended \\
\hline $\begin{array}{c}\text { Rainfall and other } \\
\ldots \ldots \ldots \ldots \ldots \ldots \ldots \ldots \ldots \ldots \\
\end{array}$ & Solid particles, chemical's toxic \\
\hline $\begin{array}{c}\text { Precipitation } \\
\ldots \ldots \ldots \ldots \ldots \ldots \ldots \ldots \ldots \ldots \ldots \ldots \ldots\end{array}$ & Elements, radioactive fallout \\
\hline \multicolumn{2}{|l|}{ INDUSTRY } \\
\hline Steel mills and furnaces $\ldots \ldots \ldots \ldots \ldots \ldots$ & $\begin{array}{c}\text { Suspended solids, lubricating oils, heat, } \\
\text { acid heavy metal dissolved organic } \\
\text { solvents }\end{array}$ \\
\hline Paper mills & $\begin{array}{l}\text { Suspended solids, high BOD, acid } \\
\text { dissolved organic foaming agents, } \\
\text { chemical and slimicides }\end{array}$ \\
\hline Motor vehicles and parts & $\begin{array}{l}\text { Oil heavy metals, suspended solids, } \\
\text { alkali's acids, cyanide organic solvents }\end{array}$ \\
\hline $\begin{array}{c}\text { Textile mill } \\
\ldots \ldots \ldots \ldots \ldots \ldots \ldots \ldots \ldots \ldots \ldots \ldots \ldots\end{array}$ & High BOD, suspended solids \\
\hline $\begin{array}{c}\text { Products } \\
\ldots \ldots \ldots \ldots \ldots \ldots \ldots \ldots \ldots \ldots \ldots \ldots \ldots \ldots \\
\end{array}$ & $\begin{array}{l}\text { Grease, bleaches, dyes salt organic } \\
\text { solvent, pesticide }\end{array}$ \\
\hline $\begin{array}{c}\text { Petroleum refining } \\
\ldots \ldots \ldots \ldots \ldots \ldots \ldots \ldots \ldots \ldots \\
\end{array}$ & High BOD, phenols oils \\
\hline Chemical & Various metals, salts, or Ganic substance. \\
\hline
\end{tabular}




\begin{tabular}{|c|c|}
\hline Fruit and vegetable processing ...... & High BOD, suspended solids \\
\hline $\begin{array}{c}\text { Breweries } \\
\ldots \ldots \ldots \ldots \ldots \ldots \ldots \ldots \ldots \ldots \ldots\end{array}$ & High BOD, suspended solids \\
\hline $\begin{array}{c}\text { Leather tanning } \\
\ldots \ldots \ldots \ldots \ldots \ldots \ldots \ldots \ldots \ldots \ldots\end{array}$ & $\begin{array}{l}\text { High BOD, suspended solid's alkali's } \\
\text { sulphides. }\end{array}$ \\
\hline Meat and poultry products...$\ldots \ldots \ldots \ldots$ & $\begin{array}{l}\text { High BOD, suspended solids, feathers, } \\
\text { bones }\end{array}$ \\
\hline $\begin{array}{c}\text { Dairy products } \\
\ldots \ldots \ldots \ldots \ldots \ldots \ldots \ldots \ldots \ldots \ldots\end{array}$ & $\begin{array}{l}\text { High BOD, sanitizing chemicals and soap, } \\
\text { cheese whey. }\end{array}$ \\
\hline $\begin{array}{c}\text { Plastic and resins } \\
\ldots \ldots \ldots \ldots \ldots \ldots \ldots \ldots \ldots \ldots \ldots \ldots \ldots \ldots \ldots\end{array}$ & Various organic, high \\
\hline Water craft & $\begin{array}{l}\text { COD, Raw sewage, oils, litter wash water } \\
\text { suspended solids bacteria and viruses. }\end{array}$ \\
\hline \multicolumn{2}{|l|}{ STEAM-ELECTRIC AND NUCLEAR } \\
\hline $\begin{array}{c}\text { Power plant } \\
\ldots \ldots \ldots \ldots \ldots \ldots \ldots \ldots \ldots \ldots \ldots \ldots \ldots \ldots \ldots\end{array}$ & Thermal pollution \\
\hline
\end{tabular}

Source: Isirimah, 2000.

Pollution and contamination from such sources manifest itself in the form of increased acidity, and higher concentration of nutrients, sediments, salts, trace metals, chemical and other toxins, as well as harmful pathogenic organisms that may thrive in warmer waters. Nutrients enrichments has become most widespread water quality problems, severely degrading freshwater and coastal ecosystem (UNESCO, 2009)

According to millennium ecosystem assessment, 2005; the biodiversity of the freshwater ecosystems has been degraded more than any other ecosystem including tropical rainforest. Most polluted freshwater ends up in the oceans, causing serious damage to many coastal areas and fisheries, thereby constituting a major challenge to ocean and coastal resources management (UN - Water 2011). Apart from upsetting human health, the degradation of ecosystem through polluted water affects humans indirectly as fisheries and biodiversity are destroyed threatening food production and other benefits to mankind. For example, the following are some of the reported consequences of water pollution:

i) In Europe, more than $40 \%$ of freshwater fish species and $40 \%$ of amphibians are in imminent danger of extinction (UN - Water 2011).

ii) In south Africa, nearly two thirds of freshwater species are considered threatened or endangered (UN - Water 2011).

iii) The rendering of Scandinavian lakes fishless because of gaseous pollutants that originated elsewhere in Europe (Faniran, 1992).

iv) The discharge of waste water containing red phosphorus plant into placenta bay in new found land, Canada, between 1968 and 1969 was reported to have wiped out several herrings from the bay. The episode was called "red - herring disaster" (Faniran, 1992)

v) In 1953, the calamity of mercury poisoning of the fishing community in Minamata bay, Japan was reported. The incident claimed over 80 lives with 900 injured, while several were either crippled or deformed through the consumption of fish containing mercury caught from the bay (Faniran, 1992). 
vi) Also in Japan, the Itai - Itai disease (cadmium poisoning) was reported to have plagued Toyoma city region between 1955 and 1973 when industrial effluent containing cadmium (also lead and zinc) from a miring waste water was discharged into river Jintsu. This led to the contamination of the river being used by the community for irrigating rice field. Through the consumption of rice grown therein, the pollution claimed 50 lives with several others at victims (Faniran 1992)

vii) Every year 1.8 million people die from diarrheal disease attributed to unsafe water or poor sanitation and hygiene (WHO, 2004)

viii) In 2009, over 50 countries still reported cholera to WHO and approximately 200 million people around the world are infected with Schistosomiosis, a depilating water borne parasite diseases (WHO, 2010).

In the Nigerian environment, the following cases have been reported:

i) In 1984, several fishes were found dead and floating in the Lagos lagoon along marina due to the discharge of toxic wastes and in industrial effluent into the river body. (Faniran 1992).

ii) Existence of coastal degradation especially by excessive erosion and flooding. The effects are most pronounced in Lagos, Rivers, Cross Rivers, Ondo and Ogun States. (Anina, 1989)

iii) Coastal and marine pollution caused largely by oil exploration, production and marketing activities, both in the coastal areas and offshore.

iv) Scepage of oil into surface waters and ground waters in the vicinity of petroleum refineries and petroleum products depots in Kaduna, Warri and Port Harcourt. (Aina 1989) .

v) Accidental discharge of water containing high ammonia level into Okirika river in 1988 from NAFCON (a fertilizer company), at Onne, near Port Harcourt, caused massive fish kill and socio-economic problems for the artisanal fishery industry in the surrounding village. The villagers then were claiming about N3 Million compensation from the company (Feniran 1992).

vi) Combined industrial effluent from Ikeja industrial estate through WEMABOD treatment plant which had broken down, spilled into Idimangoro area at Agege Lagos in 1970 due to the blockage of one of the man-holes on the effluent channel. Drinking well waters in the area were grossly polluted. The foundation of one the houses affected by the spillage caved in, and the occupants were evacuated (Faniran 1992).

vii) Petroleum product spillage from the Kaduna Refinery into Romi and Rido rivers in 1987. Well waters in Rido village as well as the Rido and Romi rivers were grossly polluted. Compensation of more than N3 million had been paid to the villagers. (Faniran 1992).

viii) Water hyacinth "outbreaks" in Lagos port and harbor as well as along the coastal creeks and lagoons. These have serious implication on water transport, port operations, recreational amenities, fisheries and tourisms. (Aina 1989).

There are no reliable estimates of the total burden of ill - health resulting from water contaminated by domestic, industrial and agricultural discharges. Poor water quality also has a direct impact on water quantity in a number of ways. Polluted water that cannot be used for 
drinking, bathing, industry or agriculture effectively reduces the amount of useable water within a given area.

\section{STRATEGIES TO COMBAT WATER QUALITY PROBLEMS}

There are four fundamental strategies to combat water quality problems that can form the basis of policy solution for improving water quality (WHO, 2010).

These are:

i) Prevention of pollution

ii) Treatment of polluted water

iii) Safe use of waste water

iv) Restoration and protection of ecosystem.

\section{i) Prevention of pollution}

Pollution prevention strategies focus on the reduction or elimination of waste at the source. Prevention is widely regarded as the cheapest, easiest and most effective way to protect water quality. In industry, solution includes reformulating products so that they produce less pollution and require fewer resources (including water) during their manufacture. In agriculture, reducing the use of toxic materials for pest control, nutrient application and overall water usages through precision farming can reduce pollution (FAO 1996; FAO 2003). In human settlement, the most obvious solutions include increasing improved sanitation coverage, consideration of settlement design (such a type of materials used for construction), the location of storm water, as well as reducing waste water production (UNEP 2010).

\section{ii) Treatment of polluted water}

In cases where contaminants result from domestic, industrial or agricultural activities, waste water must be treated before discharging. The appropriate treatment options depend on the circumstance and intended after use. For example, to supply water for larger settlements modern multiple stage water treatment plants are typically required. At the community level, solution may include solar stills, and smaller scale filtration and disinfection plants. At the household level, solution may include boiling, solar pasteurization, simple water filter, solar water infection and chlorine treatment. While several of the option mentioned may also be appropriate for treatment of water for industrial use, agricultural source water can, in some cases be of much lower quality, especially where harmful contaminants that can accrue in soil and crops are absent (UN - water 2011).

\section{iii) Safe use of waste water}

Waste water is usually disposed of into water bodies ideally following treatment to render it environmental safe. However, it can safely be used sometimes even untreated in circumstances where impacts on human health and environment are well understood and all possible action is taken to eliminate risks (WHO/FAO/UNEP, 2006, FAO 2010). If well regulated, safe use of waste water for example, in agriculture, can reduce the pressure exerted by human activities on existing fresh water resources and augment water supply in water scarce and semi - arid zones and in rapidly growing peri - urban setting (Choukr - Allah, 
2004). Furthermore, waste water can be a source of nutrients and when properly managed is potentially valuable for certain agricultural uses, reducing the need for expensive chemical fertilizer (Scott et al 2004). Additionally, agriculture may act as a form of biological treatment, moving nutrients from water that otherwise may pollute water courses. In peri urban and rural areas, treated human waste water can be a viable source of water for reuse, after applying ecological sanitation. It involves the separation of urine and faecal matter. Sterile urine may be applied directly to plants while fecal matter is composted until it is safe for land application. This approach has been implemented in several countries and regions including China, India, Burkina Faso, Kenya, Niger, Sweden, and parts of Eastern Europe (UNEP 2010). By re - cycling water and using dry pre - stored human wastes, jobs are created for local populations as well as market opportunities for provision of indigenous fertilizers and soil conditioners for agriculture. Some industries, such as food and processing industry utilized large volumes of water, and often also discharge considerable quantities of waste water. Such waste water can be reuse in other applications that do not require high quality, or apply appropriate technologies to process waste water for producers requiring water of high quality. Examples can be derived from Namibia and Singapore, where fresh water resources for both industrial and human consumption are supplemented with treated waste water (UN - water 2011).

\section{iv) Restoration and protection of ecosystem.}

Healthy ecosystem provide water quality benefits in the form of water purification, often at far lower cost than subsequent engineering efforts to clean contaminated water (Costanza et al 1997). When water systems, including watersheds, are adversely impacted by water quality, strategies to remediate pollution and restore systematic health and function are important (UNEP 2010) Ecological restoration is the process of assisting the recovery of an ecosystem that has been degraded, damaged or destroyed (Society for Ecological Restoration International, 2004). Strategies for fresh water restoration can be straight forward as removing up stream dams and restoration of rivers and wet lands. One of the well - established approaches that can be used to deal with pollution from both point and non - point sources is eco-hydrology (Costanza et al, 1997). An eco-hydrological approach is based on the understanding of the inter relationships between the ecological processes and the water cycles in a given catchment and supports the role of ecosystem processes in water quality improvement. Eco-hydrology can address water related threats such as reducing flood risk by creating wet lands that prevent pollutants from entering water ways. Examples of ecohydrology approaches can be found worldwide including Iraq, Japan, and Poland (UNEP 2010).

\section{CONCLUSIONS AND RECOMMENDATIONS}

Water is our richest and most natural resources which should not be polluted. Since water quality problem can be prevented, it is necessary and imperative to protect our water bodies and the environment in general from pollution through appropriate legislation and guidelines.

The industrial waste waters must be properly treated and closely monitored. Limitation guidelines for all industries have been prescribed by various regulatory national and international agencies such as FAO, and FEPA to control water quality and effluents of specific industries. Strict enforcement of these regulations will reduce the present level of 
pollutions introduced by uncontrolled effluent discharges and waste waters from our industries and protect the water bodies and the environment. These regulations should also be extended to domestic waste discharge for same reasons. To be effective and achieve meaningful results, those to be policed must be given proper environmental education. The society at large must be sensitized to the need for environmental protection. Public literacy campaign and mass education on environmental problems including water pollution and prevention is a must to make the nations a fully environmentally literate society. The more sound and understanding of the environment the more effective it can be at the service of human beings. Therefore we have a collective responsibility to keep our environment and make it safe to live in. Taking these bold steps locally, nationally and internationally will mean a better water quality for our society and future generation. The joy of swimming in local rivers and lakes and fishing for recreation and sustenance will then thrive again. Clean water in life. We already have the know-how and skills to protect our water quality. What is now needed is the will.

\section{References}

[1] Aina E. O. A (1989) Environmental Protection. Proceedings of the $14^{\text {th }}$ Annual Conference of Chemical Society of Nigeria page 54.

[2] Amund O. O., Odubella M. (1991). Coli form Bacteria and Faecal steroid as indicators of water quality. Proceedings of first National conference on Water Quality monitory status in Nigeria, Kaduna Pp. 116-122.

[3] Ayers R. S., Westott D. W. (1994.) Water Quality for agriculture. FAO Irrigation and Drainage Paper 29. Rev. 1, FAO, Rome .

[4] Choukr Allah R. (2004) Wastewater Recycling and Reuse as a Potential Resource for Water Saving in the Mediterranean Region. Agadir, Morocco, 2004. (http:// resources.ciheam.org/om/pdf/a66/00800305.pdf).

[5] Costanza R. R., d' Arge R. de Groot, S. Farberk, M. Grasso, B. Hannon, K. Limburg, S. Naeem, R. V. O’Neill, J. Paruelo, R. G. Raskin, P. Sutton, M. Van den Bett, Nature 387 (1997) 253-260. (http://www.ukm.edu/giee/publications/nature Paper. pdf )

[6] Faeth P. (2000). Fertile Ground: Nutrient Trading's Potential to cost-Effectively Improve Water Quality. World Resources Institute, Washington, DC.

[7] Faniran J. A. (1992). Chemistry and Environmental Protections: An overview of the Nigerian Situation. Lecture delivered at the Ordinary Meeting of the Nigerian Academy of Science held at the Nigerian Institute of international Affairs, Victoria island, Lagos on 11 April, 1992.

[8] Food and Agriculture organization of the United Nations (FAO) 1996 Control of Water Pollution by Agriculture. FAO, Rome.

[9] Development of Framework for Good Agricultural Practices. Committee on Agriculture, Seventeenth session. Rome, $31^{\text {st }}$ March $4^{\text {th }}$ April 2003. (http://www.fao.org/docrep/meeting/006/y8704e.htm) 
[10] The Wealth of Waste: The Economics of Waste Water use in Agriculture FAO Water Report 35. FAO, Rome

[11] Ghassemi F., A. J. Jakeman, H. A. Nix (1995), Stalinization of Land and Water Resources. Human Causes, Extent, Management and Case Studies. Center for Resources and Environmental studies, Australian national University, Canberra, Australia, 1995.

[12] Isirimah N. O. (2000). Soil and Environmental Pollution Management. Nichdana Publishers $\mathrm{C} / \mathrm{O}$ Ezirim press IB New Market Lane Owerri, Pp. 50-60.

[13] Mahvi A. H, J. Nouri, A. A Babaaei, R. Nabizadh, International Journal of Environmental Science and Technology 2(1) (2005) 41-47.

[14] Millennium Ecosystem Assessment (2005). (R Hassan, R Schols and N Ash, eds.) Ecosystems and Human Well- Being: Current State and Trends. Findings of the Conditions and Tends Working Group (Millennium Ecosystem Assessment Series) Island Press Washington, DC 2005.

[15] Michael A. M. (1999). Irrigation .Theory and Practice .Vikas Publishing House, PVT Ltd New Delhi Pp. 741-790.

[16] Morris B. I., A. R. I. Lawrence, P. J. C. Clinton, B. Adams, R. C. Calow, B. A Klinek, (2003). Groundwater and its Susceptibility to Degradation. A Global Assessment of the problem and Options for Management. Early Warming and Assessment Rreport Series, RS 03-3 United State Environment Programme. Nairobi Kenya.

[17] Revenga C., G. Mock (2000). Dirty Water: Pollution Problem Persists In : Pilot Analysis of Global Ecosystems: Freshwater systems; http//earthrends.wri/org/text/water-resources/feature_16.htm.

[18] Scott C. A., N. I Farugui, I. Rachid-Sally, eds. (2004). Waste Water Use in Irrigated Agriculture: Coordinating the livelihood and Environmental Realities, CAB International. Wallingford United Kingdom 2004. (http://www.1drc.ca/openebooks/112-4

[19] Society for Ecological Restoration (2004). International Science and Policy Working Group. The SER International Primer on Ecological Restoration. Society for Ecological Restoration International Tucson, 2004 (http:///www.ser.org/pdf/primer 3.pdf)

[20] UNESCO (2009). United Nations World United Assessment programme. The United Nations World Water Development Report 3: Water in Changing World. UNESCO, Paris, and Earthscan, London (http://webworld.unesco.org/water/wwap/wwdr/wwdr3/

[21] UN-Water (2011). UN Water Policy Brief. Water Quality http:/www.unwater.org

[22] World Health Organization (WHO) (2004). Water, Sanitation and Hygiene links to Health: Facts and Figures. Updated November 2004. WHO, Generva, 2004. (http://www.who.int/water_sanitation_health/publication/ facts2004/en/)

[23] World Health Statistics (2010). WHO, Geneva, (hhtp://www.who.int/whosis/whostat/2010/en/index.html).

[24] World Health Organization, Food and Agriculture Organization of the United Nations Environment Programme (WHO/FAO/UNEP) Guildlines for the Safe Use of Wastewater, Excreta and Grey Water. Volume II Wastewater Use in Agriculture, World Health Organization, Geneva, 2006. 
[25] World Health Organization and United Nations Children's Fund Joint Monitoring Programme (JMP) for Water Supply and Sanitation. Progress on Drinking Water and Sanitation: Special Focus on Sanitation. UNICEF, New York, and WHO, Geneva, 2008 (http://who.int/water_health/momitoring/jmp2008/en/index.htm)

[26] Ebad Bashiri, Jahanbakhsh Bashiri, Farhad Karimi, International Letters of Natural Sciences 3 (2013) 7-20.

[27] Daniszewski P., International Letters of Chemistry, Physics and Astronomy 3 (2012) 86-92.

[28] Daniszewski P., International Letters of Chemistry, Physics and Astronomy 4 (2012) 112-118.

[29] Daniszewski P., International Letters of Chemistry, Physics and Astronomy 5 (2012) 80-87.

[30] Daniszewski P., Konieczny R., International Letters of Chemistry, Physics and Astronomy 4 (2013) 91-97.

[31] Daniszewski P., Konieczny R., International Letters of Chemistry, Physics and Astronomy 8(3) (2013) 269-278.

[32] Daniszewski P., Konieczny R., International Letters of Chemistry, Physics and Astronomy 8(3) (2013) 279-287.

[33] Singare P. U., Talpade M. S., Dagli D. S., Bhawe V. G., International Letters of Chemistry, Physics and Astronomy 8(2) (2013) 94-104. 